\title{
Introduction: Language Matters
}

\section{Tine Roesen}

This volume presents a variety of topics, amply testifying to the relevance of modern language studies today. The contributions analyse linguistic and literary representations of burning issues such as climate change and migration, as well as the ever-difficult memory of Holocaust, and the eternal question of aging. They highlight the intricate relations between linguistics and politics in Columbia, Russia, and Egypt, and reflect on appropriate methods of language learning in the twenty-first century. Furthermore, diverse analytical methods are applied, ranging from philology and linguistics to discourse analysis and narrative analysis, and employing concepts such as nostalgia, identity, and chronotope.

In addition to this impressive range of topics and methods, I would like to highlight a third characteristic of the volume: the wide variety of languages represented in the analyses. The authors do not make a point of this; to them, it is obviously completely normal to read and analyse texts in Norwegian, English, French, Italian, Russian, Arabic, or Spanish — and to present their results in English, the academic lingua franca in our part of the world. Not only does this fact deserve to be mentioned, but I also believe that, if we want to argue more clearly the relevance of modern language studies, this is actually a crucial point: that the specific language matters. Proficiency in specific languages, I thereby imply, enables us to access, understand, and enter into dialogue with the cultures and cultural identities expressed in these languages.

In the following, I would like to make a few observations pertaining to this overall point, in addition to considering language matters (in the second sense) in the light of general perceptions of languages and 
language studies in society, as well as developments within the field of language studies. My point of departure is the language situation in Denmark and the Nordic countries, but I also hope to make some points of general relevance, or at least general interest.

\section{Foreign languages are important}

Around the world, it is not difficult to argue the need for proficiency in at least a few foreign languages. As individuals, and as societies and states, we are faced with the fact of a globalised market and globalised media, as well as with local and national reactions to this globalisation. As this volume shows, we also face global challenges in the form of climate change, migration, and terrorism, as well as reactions to these challenges; and, obviously, violent clashes of culture and religion concern us all. In order to attempt to understand all this, we need historical, political and cultural knowledge, in addition to apt analytical approaches. However, if we want to do more than understand our own local or national developments, and to do more than discuss among ourselves, we also obviously need to study foreign languages and cultures.

Indeed, and somewhat paradoxically, the more "nationalistic" our reactions to global challenges, the more foreign languages we need in order to communicate across borders, due to the fact that national identity is often defined as rooted in the national language, which must be protected, promoted abroad and allowed dominance at home (cf. Lunde's article in this volume on language legislation in contemporary Russia). Not only globalisation itself and reactions to it, but also recent developments such as the rising global influence of China and intra-European tensions-most importantly the inclusion of Eastern European countries and languages in the Eu and, most recently, Brexit-point to the fact that we are approaching a situation in which knowledge of one foreign language is not sufficient. The expectation of (Western) globalisation optimists that English would serve as a kind of "cultural calculator," to use the expression of Danish scholar Hans Lauge Hansen (Hansen 2004, 114), does not seem anywhere near realisation. To repeat with a twist: English is the lingua franca in our part of the world, but not in all parts of the world. A new Danish book entitled (my translation) "World Citizens with No Language" presents ample evidence of our anglocentric fallacy,

1 For more on anglocentricity in European language policies, see Phillipson 2003. 
as when Danish companies indicate that they lost contracts or control because of a (French, Spanish, Polish, Russian, German) business partner's inadequate English; or when the lack of success of the Copenhagen Climate meeting in 2009 was, reportedly, partly attributed to the absence of interpreters in a crucial meeting conducted solely in English (Verstraete-Hansen \& Øhrgaard 2017, 41-43).²

Judging by the conclusions of recent conferences, reports and books on foreign languages and language studies in Norway, the UK and Denmark-including, in the latter two countries, ideas for a national language strategy-political and expert levels seem to agree that languages serve an important function in contemporary societies, both culturally and economically. At the same time, we see a fascination, not least among young generations, with cultural products from outside the Western and American hemisphere, representing less familiar cultures and languages; for example, the Korean YouTube hit "Gangnam style" (2012) or the currently popular clothes designer Gosha Rubchinsky with his demonstratively Soviet Russian style, including Cyrillic logos and adornments.

Nevertheless, increased exposure to foreign cultures and languages, despite popular fascination, does not as yet seem to have led to an increased interest in studying and achieving proficiency in these foreign languages themselves. There are many possible explanations for this. Perhaps this is considered too difficult, perhaps we want the exotic to remain exotic, or perhaps language is not, in this context, recognized as important to the desired exchange, effect or entertainment. Moreover, as translators and interpreters around the world can testify, even when language barriers cause serious problems, these are rarely considered serious enough to be included in business strategies (Verstraete-Hansen \& Øhrgaard 2017, 45-6). However crucial to negotiations, exchanges and operations-including hospital operations - the profession of translators and interpreters is poor in both economic and symbolic capital, and translator associations in many countries are kept busy securing even a

2 Verstraete-Hansen \& Øhrgaard's other point in this connection is that the blame is invariably laid on the non-English speaking partner, and that Danish companies fail to realise their own lack of relevant languages for dealing with countries where English does not enjoy the same status as in Denmark.

3 For a selection of publications, see the list concluding this introduction. The Danish language strategy has not yet been announced. 
basic pay and the minimum of citation credits defined in the copyright laws. ${ }^{4}$ Apart from possible lack of courage or exoticization, what seems to be at play is a banalisation of what it means to learn and master a foreign language, and, consequently, a reduction of the act of translation to that of a "linguistic calculator," in line with Google translate-a banalisation based on ignorance not only of the complicated learning processes involved in language learning (see the didactics articles in this volume), but also of the elaborate, and still far from perfect, software developed for machine translation.

\section{Foreign language studies in a critical situation}

So, reports and strategies tell us that foreign languages are important, and yet, language studies all over the Western world are currently experiencing a crisis: every month, foreign language programmes are being shut down for financial reasons. Foreign language studies have difficulty competing with more prestigious programmes and attracting enough students to secure the programme economy, probably partly due to the low economic and symbolic capital previously mentioned. And, more generally, as critics such as Martha Nussbaum and Stefan Collini have pointed out, the dominant trends in contemporary university management world-wide-mercantilism and instrumentalisation - are damaging for universities as such, ${ }^{5}$ but especially damaging for the Humanities. In Not for Profit: Why Democracy Needs the Humanities (2010), Nussbaum identifies an international "silent crisis" in contemporary university education: it is viewed as primarily a tool for economic growth and therefore managed "along growth-oriented lines" (127), to the detriment of democratic societies and global cooperation. Collini, in his book What Are Universities For? (2012), calls this development a "mercantilism of the intellect" which, in combination with a "distrust of reasoned argument" (17), leads to a situation where only that which can be measured and counted is valued. In Denmark, accordingly, the quality of a university programme is measured only in terms of what

4 See for example European Council of Literary Translators' Associations (www.ceatl.eu).

5 These points are increasingly heard from inside various universities, see e.g. Halfmann \& Radde 2015, as well as the Danish blog professorvaelde.blogspot.dk, the University of Aberdeen project and manifesto at reclaimingouruniversity.wordpress. com, and the "Council for the Defence of British Universities" (cdbu.org.uk). 
can be quantified: the student/teacher ratio, the percentage of research staff, the number of students applying for the programme (the more the better), and the number dropping out (the fewer the better); in addition, in many universities a minimum of teaching hours per week must be met: for BA programmes 12 hours, for MA programmes 8 hours, regardless of the size of the auditorium ( 2 or 200 students). In the same vein, we see a utilitarian instrumentalisation of knowledge in our educations. Programmes must prove that they have "impact," that they lead directly to identifiable employment, and that they are relevant and worthwhile in economic cost-benefit terms.

Thus, universities seem to be managed ever more like (only) private companies, and ever less like (also or primarily) institutions of higher education. They are meant to compete with each other-most visibly in rankings-both for profit and prestige, and for themselves as well as on behalf of their states/nations. Education in the sense of Bildung seems to have been forgotten or discarded, as regards both the individual and society, and since it is very difficult to measure and compare the qualities and impact of critical thinking, self-reflection, language-based cultural understanding and historical knowledge, the Humanities (and some branches of the Social sciences) are probably suffering the most from this kind of public management.

Moreover, foreign language studies, in addition to being in the same trouble as the Humanities and suffering from low esteem in society in general, seem to have yet another problem, which may make us more vulnerable to current management principles, as well as to competitive criticism from other disciplines in terms of academic legitimacy. The problem is that we do not have a clear theoretical or methodological profile of our own, and that the language proficiency component is therefore often seen as a mere practical appendix.

\section{The concepts, theories and methods of modern language studies}

The contributors to this volume show the ability and willingness of modern language studies to engage with broader theoretical developments in the Humanities and Social sciences. They are able, therefore, to apply the most relevant methods directly to original text sources, and to the culturally embedded, linguistic details of these texts. This makes for very strong analyses. At the same time, however, this very diversity may also 
be seen as a sign of an extremely inclusive and therefore somewhat diffuse scientific paradigm. Hans Lauge Hansen's diagnosis is that the scientific paradigm of modern language studies is suffering a crisis (Hansen 2005; see also Hansen 2004).

Hansen has called for a return to and revival of philology in the form of a "philology of culture," taking this concept from German Anglicist, Herbert Grabes (see Grabes 2002). Tracing the development of language studies from classical philology, through the (romanticist and historicist) national philologies of the nineteenth century to the modern language studies of the twentieth century, Hansen has shown how modern language studies, increasingly influenced by developments within the now separately organised comparative humanities and social sciences-history, linguistics, literary analysis, anthropology, sociology, etc.- - have incorporated structuralism, Marxism, communications theories, poststructuralism, and cultural analysis, as well as the pragmatic turn within linguistics, the linguistic turn within cultural and social studies, and the cultural turn within literary studies (Hansen 2005, 305-11). It goes without saying that a single modern language programme (with ever fewer employees) cannot possibly incorporate all of this; yet, depending on the researchers involved in a programme and the relevance to the studied language and culture, any of these theories and approaches may be researched and taught. In addition, and somewhat ironically I would add, the so-called linguistic turn within cultural studies, with its focus on often rather abstract linguo-philosophical aspects, seems to have to some degree displaced rather than supported the study of concrete languages and specific linguistic issues. Likewise, the sociological tendency and favouring of popular culture within cultural studies, including the dethroning of elite culture, has not exactly been supportive of a philological interest in linguistic detail, creative individuality, and, thus, "high" literature.

It is no wonder, then, that modern language students are often confused about their method and perhaps also embarrassed about their status. "[P]hilology was the queen of the human sciences" and "synonymous with humanistic intellectual life," James Turner states in his Philology: The Forgotten Origins of the Modern Humanities (2014). Nowadays, it would seem, our students are hard-working, underrecognized ants, and the term "philology" is most often used in a derogatory sense, signalling 
something obsolete and not particularly useful. This also, I would argue, contributes to the crisis in language studies: if we cannot explain our academic value to ourselves, it is also difficult to convince others.

Can we change this? Can we define and clarify our scientific paradigm for the benefit of our own research, as well as our programmes, students and societal status?

\section{The strengths of modern language studies}

The university descendants of traditional philology have taken many forms and names-philology, modern language studies, language-based area studies, or area studies with a language component. At the core of all of these programmes, however, lies the question of how much (or how little) language is "necessary." In line with the banalisation of language skills, it is often argued-even from within the Humanities-that language serves best as an "add-on," i.e. as a practical tool supplementing "real" and essential academic competencies. However, this would potentially reduce modern language students to "tourists" rather than experts. Without excellent language skills, there is no access to all of the texts belonging to a given nation, society, and culture; and by implication, the academic study of foreign nations, societies and cultures, no matter how theoretically well-informed, would be based on second-hand knowledge and dependent on existing translations and interpretations. But who will produce new translations and interpretations? It is a simple truth but it needs to be reiterated: Without the continuous education of foreign language experts, there will not be any additional fact-finding research, translations and interpretations to lean on in the future.

In the "philology of culture" promoted by Hansen, the concrete reading of concrete texts is of central importance; in other words, the text is the crucial, common object of modern multidisciplinary language studies (Hansen 2005; Hansen 2004). Hansen is himself primarily concerned with the study of literary texts, but his concept of "text" is broad, inspired by Bakhtinian dialogism as well as semiotics, and his credo can, in fact, be used to encompass all kinds of cultural and linguistic practices, as long as we insist that the concrete reading and interpretation of "texts" in their original language and form is the strength and value of language studies. 
Norwegian Germanicist, Helge Jordheim's (2001) proposal for a renewal of philology also focuses on literary texts and "the art of reading," but has been extended to include conceptual history (Koselleck), discouse analysis (Foucault), and speech act theory (Skinner); in other words, a more concentrated scientific paradigm, building on the strengths of linguistic competencies, which may, however, as this volume shows, also include the reading of non-literary texts.

To conclude, continuous research in foreign languages and cultures, as well as a continuous flow of language studies graduates who have studied a variety of languages, are necessary for the future production of not only original and strong, language-based analyses, but also of translations and textual commentaries; these may provide comparative disciplines and non-scholars with access to otherwise unknown and incomprehensible texts, be it YouTube videos, demonstration slogans, policy documents, archival sources, or works of literature, popular as well as high. That is the relevance of modern language studies, whatever we choose to call them.

\section{References}

Collini, Stefan. 2012. What Are Universities For? London: Penguin.

Grabes, Herbert. 2002 . "The Cultural Turn of Philology." Changing Phi-

lologies, edited by Hans Lauge Hansen, 51-62, Copenhagen: Museum Tusculanums Forlag.

Halffman, Willem and Hans Radde. 2015 (Dutch original 2013). "The Academic Manifesto: From an Occupied to a Public University." Minerva 53:165-87.

Hansen, Hans Lauge. 2004. "Towards a New Philology of Culture." The Object of Study in the Humanities, edited by Hans C. Julio Jensen, 11326. Copenhagen: Museum Tusculanums Forlag.

Hansen, Hans Lauge. 2005. "Kapitel VI: Globalisering, fremmedsprog og litteratur." Littercer erfaring og dialogisme, 293-322. Copenhagen: Museum Tusculanums Forlag.

Jordheim, Helge. 2001. Lesningens vitenskap-Utkast til en ny filologi. Oslo: Universitetsforlaget.

Nussbaum, Martha C. 2010. Not for Profit: Why Democracy Needs the Humanities. Princeton/Oxford: Princeton University Press. 
Phillipson, Robert. 2003. English-Only Europe? Challenging Language Policy. London: Routledge.

Turner, James. 2014. Philology: The Forgotten Origins of the Modern Humanities. Princeton/Oxford: Princeton University Press.

Verstraete-Hansen, Lisbeth and Per Øhrgaard. 2017. Sprogløse verdensborgere: Om en uddannelsespolitik, der forsvandt. Copenhagen: DJØF forlag.

Select reports and recommendations

2005. Språk åpner dører: Strategi for styrking av fremmedspråk i grunnopploeringen 2005-2009. Oslo: Utdannings- og Forskningsdepartementet, https:/www.regjeringen.no/globalassets/upload/kilde/ufd/ bro/2005/0003/ddd/pdfv/253707-sprak_apner_dorer.pdf.

2008. Lisbeth Verstraete-Hansen. Hvad skal vi med sprog? Holdninger til fremmedsprog $i$ danske virksomheder $i$ et uddannelsespolitisk perspektiv. Copenhagen: CBS, http://openarchive.cbs.dk/bitstream/handle/10398/9176/Verstraete-Hvad_skal_vi_med_sprog.pdf?sequence $=1$. 2008 Lisbeth Verstraete-Hansen and Robert Phillipson. Fremmedsprog til fremtiden: Sprogpolitiske udfordringer for Danmark, http://www. xn--sprkfrsvaret-vcb4v.se/sf/fileadmin/PDF/Fremmedsprog_for_ fremtiden.pdf.

2011. Sprog er nøglen til verden. Anbefalinger fra arbejdsgruppen for uddannelse i fremmedsprog. Copenhagen: Ministeriet for Videnskab, Teknologi og Udvikling, http://ufm.dk/filer/publikationer/2011/sprog -er-noeglen-til-verden/index.htm.

2013. Mette Skovgaard Andersen and Lisbeth Verstraete-Hansen. Hvad gør vi med sprog? Behov for og holdninger til fremmedsprog i den danske centraladministration $i$ et uddannelsespolitisk perspektiv. Copenhagen: Copenhagen Business School, http://openarchive.cbs.dk/bitstream/handle/10398/8783/Skovgaard\%2 o Andersen\%2 O \%2 oVerstraete-Hansen\%2 o hvad\%2 o g\%C3\%B8 r\%2 ovi\%2 o med\%2 osprog pdf? sequence $=1$.

2015. The Value of Languages: Ideas for a UK Strategy for Languages. Cambridge: University of Cambridge, http://www.publicpolicy.cam. ac.uk/pdf/value-of-languages.

2016. Tanketanken om sprog-anbefalinger til at styrke sprog i gymnasiet. Copenhagen: Gymnasieskolernes lærerforeningen, http://www.gl.org/ 
uddannelse/udd.politik/Documents/T\%C3\%A6nketanken\%2 o om\% 2 osprog\% $\%$ O-\%2 o anbefalinger\%2 otil\%2 o at $\% 2$ ostyrke\%2 osprog\%2 O i\%2 ogymnasiet.pdf.

2016. Brian Arly Jacobsen and Tine Roesen. Småfagene på ToRS-En hvidbog om små optag, gode uddannelser, store forskningsbidrag og strategisk nødvendig viden. Copenhagen: University of Copenhagen, Department of Cross-Cultural and Regional Studies, http://www.epages.dk/ku/1256/html5/. 